\title{
Effect of Urea and Anhydrous Ammonia Fertilizer on Yield and Yield Component of Rice Plants. \\ Abd El-Megeed, T. M.
}

Rice Research\& Training Center, Field Crops Research Institute, Agriculture Research center, 33717 Sakha-Kafrelsheikh.

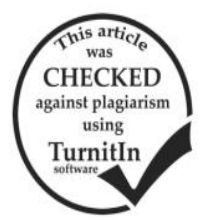

\begin{abstract}
Two field experiments were conducted in 2015 and 2016 growing seasons at the farm of Agricultural Research Station, Sakha, Kafrelsheikh, Egypt, consisted of three cultivars(Sakha106, Giza179 and Egyptian hybrid rice one) as well as seven nitrogen $(\mathrm{N})$ fertilizer treatments were added at the rate of $165 \mathrm{~kg} \mathrm{~N} / \mathrm{ha}$. Anhydrous ammonia $(82 \% \mathrm{~N})$ was injected directly into the dry soil at the depth of $20 \mathrm{~cm}$ before plant, while, urea $(46 \% \mathrm{~N})$ was applied according to the recommended of RRTC. Results revealed that application of nitrogen at $165 \mathrm{~kg} \mathrm{~N} / \mathrm{ha}$ as anhydrous ammonia recorded the highest chlorophyll content, LAI, dry matter $/ \mathrm{m}^{2}$, plant height $(\mathrm{cm})$, no. of tiller $/ \mathrm{m}^{2}$, panicle number $/ \mathrm{m}^{2}$, panicle weight $(\mathrm{g})$, panicle length $(\mathrm{cm})$ and filled grains resulted in a highest grain yield. Also, economic analysis was done. Data shows that the highest profit was recorded when full dose of Anhydrous Ammonia was applied with all varieties.
\end{abstract}

\section{INTRODUCTION}

Rice (Oryza sativa L.,) is considered one of the most important summer crops in Egypt. The productivity of rice is affected by many factors such as seed germination, $\mathrm{N}$ fertilization, and quality of the fertilizer techniques. Several studies reveal that judicious and proper use of fertilizers can markedly increase the yield and improve the quality of rice Place, et al., (1970).Panicles with a low percentage of sterile flowers permit the application of higher doses of nitrogen and produce better yields Yoshida, (1981). Modern production agriculture requires efficient, sustainable, and environmentally sound management practices. Nitrogen is normally a key factor in achieving optimum lowland rice grain yields Fageria, et al., (1997).

Nitrogen $(\mathrm{N})$ fertilizer is one of the limiting factor of rice production, but is subject to loss under wet conditions. Fertilizer Must be used with compatible $\mathrm{N}$ formulations to be effective.Nitrogen $(\mathrm{N})$ is essential for rice, and usually it is the most yield limiting nutrient in irrigated rice production around the world Samonte. et al., (2006).Fageria, (2003)and Tayefe, et al., (2011) concluded that in cereals crop such as rice, $\mathrm{N}$ accumulation is associated with dry matter production and yield of shoot and grain. The nitrogen fertilizer rates were strongly linearly the number of grain per panicle and the grain yield. The yields always increase with the addition of nitrogen fertilizer. This Clearfield that nitrogen is very important in the rice system Bagayoko., (2012).

The kind of nitrogenous fertilizer may also affect the yield and quality of the grain Gately and Kelly (1987). Some of these fertilizers, are anhydrous ammonia $(82 \% \mathrm{~N})$ and urea $(46 \% \mathrm{~N})$. In Egypt, urea is the dominant fertilized used in flooded rice soils because it is very cheapest compared to ammonium sulfate and other nitrogen sources. Anhydrous ammonia is a liquid under high pressure and must be injected at least six inches deep into a moist soil because it becomes a gas once it is released from the tank. In soil, ammonia reacts with water to form the ammonium $\left(\mathrm{NH}^{+}\right)$ion, which is held on clay and organic matter. Anhydrous ammonia is generally the cheapest source of nitrogen fertilizer.

Anhydrous Ammonia, NH3, is the most basic form of nitrogen fertilizer, and the most widely used source of nitrogen for corn production in North America, due to lower cost, high $\mathrm{N}$ content, and relative stability in soils. Most of the kind of $\mathrm{N}$ fertilizers are derivatives of ammonia transformed by additional processing, which increases cost. Anhydrous ammonia (AA) uses, has increased rapidly during last decade as an alternative effective N-material (El-Mneasy, 2002) and inexpensive N fertilizer than other commercial ones (Abdel Kader-Mona, 2002). Therefore, it is widely used effectively for fertilizing different crops such as cereal, fiber and field crops as well as vegetable crops grown in soils widely different in their physical and chemical features even those planted in salt affected soils (Ali-Nadia, et al.,2002; kineber, et al., 2004 and El-Masry et al., 2006).

Anhydrous ammonia is injected 15 to 20 inches below the soil surface to minimize escape of gaseous $\mathrm{NH} 3$ into the air. It reacts with soil water to form ammonium $\left(\mathrm{NH}_{4}^{+}\right)$ions. Positively charged $\mathrm{NH}_{4}^{+}$ions react and bind strongly with negatively charged soil constituents, including clay and organic matter. As such, they are held on the soil exchange complex and not subject to movement with water.

There have been no studies evaluating the effect of application anhydrous ammonia (AA) injection and their effects on soil and rice plant characteristics. Therefore, the objectives of the current work were to highlight the relative impact of different sources of nitrogen such as anhydrous ammonia and urea on the response yield and its attributes of some different rice cultivars under normal soils conditions.

\section{MATERIALS AND METHODS}

Two field experiments were conducted at the farm of Agricultural Research Station, Sakha, Kafrelsheikh, Egypt, during 2015 and 2016 seasons. Representative soil sample was taken and subjected to chemical analysis followed the standard procedures by Cottenie et al, (1979) and page et al., (1982) and the results showed that this soil texture was clayey with $1.5 \%$ and $1.6 \%$ organic matter, $\mathrm{pH} 8.2$ and 8.26, EC 1.8 and $1.45 \mathrm{dS} / \mathrm{m}, 12.5$ and $12.6 \mathrm{mg} \cdot \mathrm{kg}^{-1} \mathrm{NH}_{4}^{+}$and 10 and $11.8 \mathrm{mg} \cdot \mathrm{kg}^{-1} \mathrm{NO}_{3}{ }^{-}$during the year 2015 and 2016 respectively.

Two sets of treatments included in the experiment are follows: Cultivars $\left\{\mathrm{V}_{1}\right.$ : Sakha106, $\mathrm{V}_{2}$ : Giza 179 and $\mathrm{V}_{3}$ : Egyptian Hybrid rice one (EHR1) $\}$ and two different nitrogen sources namely, urea and anhydrous ammonia. 
The different sources of nitrogen fertilization was applied at the rate of $165 \mathrm{~kg} \mathrm{~N} / \mathrm{ha}$. Anhydrous ammonia $(82 \% \mathrm{~N})$ was injected directly into the dry soil at a depth of $20 \mathrm{~cm}$ preplant by a blade applicator then soil leveling was done, while, urea $(46 \% \mathrm{~N})$ were applied two times; one before transplanting and the other 30 days after transplanting. The nitrogen sources and its combination applied in seven different treatments as shown in Table (1). Split plot design in a randomized complete block arrangement was used with three replications. Rice cultivars was assigned to the main plots and fertilizer doses in the sub-plot. The previous crop was wheat; a common procedure was followed in raising of seedling in seedbed. Seedlings of 30 days old were uprooted from the nursery beds carefully. Seedlings were transplanted in the well puddled experimental plots. Spacing's were given 20 X $20 \mathrm{~cm}$.

Table 1. The different treatments of nitrogen sources.

\begin{tabular}{lccc}
\hline Treatments & $\mathbf{N ~ k g} / \mathbf{h a}$ & Form of nitrogen & Methods and time of application \\
\hline $\mathrm{T}_{1}$ & 165 & Urea & --- \\
$\mathrm{T}_{2}$ & 165 & Anhydrous ammonia & Injected into soil before flooding \\
$\mathrm{T}_{3}$ & 165 & Anhydrous ammonia + Urea & $3 / 4 \mathrm{~N}$ injected into soil before flooding $+1 / 4 \mathrm{~N}$ as urea at PI \\
$\mathrm{T}_{4}$ & 165 & Anhydrous ammonia + Urea & $3 / 4 \mathrm{~N}$ injected into soil before flooding $+1 / 4 \mathrm{~N}$ as urea at late booting (LB) \\
$\mathrm{T}_{5}$ & 165 & Anhydrous ammonia + Urea & $1 / 2 \mathrm{~N}$ injected into soil before flooding $+1 / 2 \mathrm{~N}$ as urea at P.I \\
$\mathrm{T}_{6}$ & 165 & Anhydrous ammonia + Urea & $1 / 2 \mathrm{~N}$ injected into soil before flooding $+1 / 2 \mathrm{~N}$ as urea at late booting (LB) \\
$\mathrm{T}_{7}$ & 0 (control) & --- & --- \\
\hline PI: Before panicle initiation\& LB: Late Booting.
\end{tabular}

Full dose of phosphorus $36.89 \mathrm{~kg}$ P2O5. ha-1as a super phosphate $(15 \%)$ was applied as a basal dose at the time of final land preparation and incorporated well into the soil. All intercultural operations were done carefully. From transplanting to twice weeks before harvesting, a thin layer of water $(3-5 \mathrm{~cm})$ was kept on the plots. Water was cut off from the plots two weeks before harvesting 20 days after complete heading. The yield of each plot was harvested separately at full maturity. Plant sample were collected from each plot for collection of data on plant characters and yield components. The grain and straw yield weight for each plot were recorded after proper sun drying and then converter into t. ha-1. The grain yield was adjusted at $14 \%$ moisture level. The differences among the treatment were compared by multiple comparison tests using Duncan's Multiple Range Test (DMRT) (Duncan, 1955).

\section{RESULTS AND DISCUSSION}

\section{Chlorophyll content of flag leaf:}

Data cited in Table (2) show that significant varietals differences were observed in Chlorophyll content of flag leaf in two seasons. It is evident from the data that Hybrid1 and Giza179 produced significantly nearly values of chlorophyll content followed by Sakha106 which gave the lowest value of chlorophyll content in both seasons of study. Application of full dose of Anhydrous ammonia injection into dry soil before flooding introduce the highest value of chlorophyll content. Plant grown without nitrogen fertilizer had the lowest chlorophyll content. Significant variation of nitrogen fertilizer and variety were observed (Table 3 ).

Table 2. Growth characteristics at harvest as affected by rice cultivars and different treatments of nitrogen application in 2015 and 2016 seasons.

\begin{tabular}{|c|c|c|c|c|c|c|}
\hline \multirow{2}{*}{ Treatments } & \multicolumn{2}{|c|}{ Chlorophyll content (uE) } & \multicolumn{2}{|c|}{ LAI } & \multicolumn{2}{|c|}{ Dry matter $/ \mathrm{g} / \mathrm{m}^{2}$} \\
\hline & 2015 & 2016 & 2015 & 2016 & 2015 & 2016 \\
\hline \multicolumn{7}{|l|}{ Cultivars } \\
\hline$\overline{\text { Sakha106 }}\left(\mathrm{V}_{1}\right)$ & $0.6958 b$ & $0.7078 b$ & $3.091 b$ & $3.891 b$ & $411.2 \mathrm{~b}$ & $429.2 b$ \\
\hline Giza179 $\left(\mathrm{V}_{2}\right)$ & $0.7570 \mathrm{a}$ & $0.7690 \mathrm{a}$ & $4.539 \mathrm{~b}$ & $5.339 b$ & $431.5 b$ & $449.5 b$ \\
\hline Hybrid 1 (V3) & $0.7604 a$ & $0.7724 \mathrm{a}$ & $6.369 a$ & $7.169 \mathrm{a}$ & $539.7 \mathrm{a}$ & $557.7 \mathrm{a}$ \\
\hline F. test & $*$ & $*$ & $*$ & $*$ & $*$ & $*$ \\
\hline \multicolumn{7}{|c|}{ Nitrogen Treatment } \\
\hline $\mathrm{T}_{1}$ & $0.6828 \mathrm{~d}$ & $0.6948 \mathrm{~d}$ & $3.946 \mathrm{e}$ & $4.746 \mathrm{e}$ & $420.1 \mathrm{e}$ & $438.1 \mathrm{e}$ \\
\hline $\mathrm{T}_{2}$ & $0.8560 \mathrm{a}$ & $0.8680 \mathrm{a}$ & $7.403 \mathrm{a}$ & $8.203 a$ & $646.6 a$ & $664.6 \mathrm{a}$ \\
\hline $\mathrm{T}_{3}$ & $0.8137 b$ & $0.8257 b$ & $6.298 b$ & $7.098 b$ & $533.3 b$ & $551.3 \mathrm{~b}$ \\
\hline $\mathrm{T}_{4}$ & $0.7603 \mathrm{c}$ & $0.7723 \mathrm{c}$ & $5.310 \mathrm{c}$ & $6.110 \mathrm{c}$ & $499.6 \mathrm{c}$ & $517.6 \mathrm{c}$ \\
\hline $\mathrm{T}_{5}$ & $0.7348 \mathrm{c}$ & $0.7468 \mathrm{c}$ & $4.556 \mathrm{~d}$ & $5.356 \mathrm{~d}$ & $459.3 d$ & $477.3 \mathrm{~d}$ \\
\hline $\mathrm{T}_{6}$ & $0.7032 \mathrm{~d}$ & $0.7152 \mathrm{~d}$ & $2.904 f$ & $3.704 f$ & $353.3 \mathrm{f}$ & $371.3 \mathrm{f}$ \\
\hline $\mathrm{T}_{7}$ & $0.6132 \mathrm{e}$ & $0.6252 \mathrm{e}$ & $2.247 \mathrm{~g}$ & $3.047 \mathrm{~g}$ & $313.4 \mathrm{~g}$ & $331.4 \mathrm{~g}$ \\
\hline F. test & $* *$ & $* *$ & $* *$ & $* *$ & $* *$ & $* *$ \\
\hline Interaction & $*$ & $*$ & $*$ & $*$ & * & $*$ \\
\hline
\end{tabular}

Whereas:

$T_{1}$ : Recommended dose of $N$ as urea $(165 \mathrm{~kg} \mathrm{~N} / \mathrm{ha}), T_{2}$ : Recommended dose of $N$ as Anhydrous Ammonia (165 kg N/ha), $T_{3}: 3 / 4$ dose of Anhydrous Ammonia $+1 / 4 \mathrm{~N}$ as urea at panicle initiation., $\mathrm{T}_{4}: 3 / 4$ dose of Anhydrous Ammonia $+1 / 4$ dose of $\mathrm{N}$ as urea at late booting, $T_{5}: 1 / 2$ dose of $N$ as Anhydrous Ammonia $+1 / 2 \mathrm{~N}$ as urea at panicle initiation, $T_{6}: 1 / 2$ dose of $N$ as Anhydrous Ammonia $+1 / 2 \mathrm{~N}$ as urea at late booting, $\mathbf{T}_{7}$ : Control (Zero Fertilizer).

Among the treatment combination $\left(\mathrm{V}_{3} \mathrm{~T}_{2}\right)$ gave the highest value of chlorophyll content and the lowest value was from $V_{1} T_{7}$. Increase in chlorophyll content increased significantly due to nitrogen application could be attributed mainly to the role of nitrogen in the stimulation of cell division. Also, anhydrous ammonia increased the availability of nitrogen that increase the absorption of nitrogen that increase chlorophyll formation. These results are supported by the findings of Chaturvedi, (2005), who concluded that, the urea fertilizer showed significant reductions in growth and yields in most of the experiments compared with ammonium nitrogen fertilizer form. Similar 
finding was achieved by Osman, et al., (2013) and Ismail, et al., (2013). which they reported that the application of $\mathrm{N}$-fertilizers may be attributed to the fact that these nutrients being important constituents of chlorophyll and enzymes that have direct impact on vegetative and reproductive phases of plants. Debiprasad, et al., (2010), concluded that the grain and straw of rice yield were increased significantly by adding nitrogen fertilizer. Grain yield was increased significantly when $\mathrm{N}$ fertilizer at 220 $\mathrm{kg} / \mathrm{ha}$ was added, while the lowest value was recorded by control treatment (without addition of $\mathrm{N}$ fertilizer).

Table 3. Chlorophyll content of flag leaf as affected by the interaction between rice cultivars and different treatments of nitrogen application in 2015 and 2016 seasons.

\begin{tabular}{|c|c|c|c|c|c|c|}
\hline \multirow{3}{*}{$\begin{array}{l}\text { Nitrogen } \\
\text { Treatment }\end{array}$} & \multicolumn{6}{|c|}{ Cultivars } \\
\hline & Sakha106 (V1) & Giza 179 (V2) & Hybrid 1 (V3) & Sakha106 (V1) & Giza 179 (V2) & Hybrid 1 (V3) \\
\hline & \multicolumn{3}{|c|}{2015} & \multicolumn{3}{|c|}{2016} \\
\hline$\overline{T_{1}}$ & $0.6420 \mathrm{ij}$ & $0.7185 \mathrm{~d}-\mathrm{g}$ & $0.6880 \mathrm{f}-\mathrm{i}$ & $0.6540 \mathrm{j}$ & $0.7305 \mathrm{e}-\mathrm{g}$ & $0.7000 \mathrm{~g}-\mathrm{i}$ \\
\hline $\mathrm{T}_{2}$ & $0.7705 \mathrm{~cd}$ & $0.8740 \mathrm{~b}$ & $0.9235 \mathrm{a}$ & $0.7825 \mathrm{~cd}$ & $0.8860 \mathrm{~b}$ & $0.9355 \mathrm{a}$ \\
\hline $\mathrm{T}_{3}$ & $0.7605 c-e$ & $0.8380 \mathrm{~b}$ & $0.8425 b$ & $0.7725 \mathrm{cde}$ & $0.8500 \mathrm{~b}$ & $0.8545 b$ \\
\hline $\mathrm{T}_{4}$ & $0.7530 \mathrm{c}-\mathrm{e}$ & $0.7820 \mathrm{c}$ & $0.7460 \mathrm{c}-\mathrm{e}$ & $0.7650 \mathrm{c}-\mathrm{f}$ & $0.7940 \mathrm{c}$ & $0.7580 \mathrm{c}-\mathrm{f}$ \\
\hline $\mathrm{T}_{5}$ & $0.7145 \mathrm{e}-\mathrm{h}$ & $0.7535 \mathrm{c}-\mathrm{e}$ & $0.7365 c-f$ & $0.7265 f-h$ & $0.7655 \mathrm{c}-\mathrm{f}$ & $0.7485 \mathrm{~d}-\mathrm{f}$ \\
\hline $\mathrm{T}_{6}$ & $0.6625 \mathrm{hi}$ & $0.7365 c-f$ & $0.7105 \mathrm{e}-\mathrm{h}$ & $0.6745 \mathrm{ij}$ & $0.7485 \mathrm{~d}-\mathrm{f}$ & $0.7225 \mathrm{f}-\mathrm{h}$ \\
\hline $\mathrm{T}_{7}$ & $0.5675 \mathrm{k}$ & $0.5965 \mathrm{jk}$ & $0.6755 \mathrm{~g}-\mathrm{i}$ & $0.5795 \mathrm{k}$ & $0.6085 \mathrm{k}$ & $0.6875 \mathrm{~h}-\mathrm{j}$ \\
\hline
\end{tabular}

\section{Leaf area index:}

Data in Table (2) reveal that the highest value of leaf area index was observed with EHR1 followed by Giza 179. Nitrogen application Injection into dry soil before flooding significantly affected leaf area index. Maximum value of leaf area index was recorded when nitrogen application was applied as a full dose of anhydrous ammonia injected into dry soil before flooding at the rate of $165 \mathrm{~kg} \mathrm{~N} / \mathrm{ha}^{-1}$, while the lowest value was observed with control treatment. This mainly due to the role of nitrogen in physiological process. The interaction between three rice cultivars and different sources of nitrogen had significant effect on LAI during both seasons. Data in Table (4) showed that, Egyptian Hybrid ricel gave the highest LAI values when they treated by anhydrous ammonia $\left(\mathrm{T}_{2}\right.$ treatment)followed by anhydrous ammonia + urea $\left(\mathrm{T}_{3}\right.$ treatment) in 2015 and 2016, respectively. While, Sakha106 with $\mathrm{T}_{7}$ treatment (control) gave the lowest values of LAI at late booting stage in 2015 and 2016, respectively. Similar finding was achieved by Osman, et al., (2013),Chaturvedi, (2005)and Ismail, et al., (2013). which they reported that the increase in growth and yield owing to the application of $\mathrm{N}$-fertilizers may be attributed to the fact that these nutrients being important constituents of nucleotides, proteins, chlorophyll and enzymes, involve in various metabolic processes which have direct impact on vegetative and reproductive phases of plants.

Table 4. Leaf area index as affected by the interaction between rice cultivars and different treatments of nitrogen application in 2015 and 2016 seasons.

\begin{tabular}{|c|c|c|c|c|c|c|}
\hline \multirow{3}{*}{$\begin{array}{l}\text { Nitrogen } \\
\text { Treatment }\end{array}$} & \multicolumn{6}{|c|}{ Cultivars } \\
\hline & Sakha106 (V1) & Giza 179 (V2) & Hybrid 1 (V3) & Sakha106 (V1) & Giza 179 (V2) & Hybrid 1 (V3) \\
\hline & \multicolumn{3}{|c|}{2015} & \multicolumn{3}{|c|}{2016} \\
\hline$\overline{\mathrm{T}_{1}}$ & $2.8771 \mathrm{~m}$ & $3.920 \mathrm{ij}$ & $5.040 \mathrm{gh}$ & $3.677 \mathrm{k}$ & 4.720gh & $5.840 \mathrm{f}$ \\
\hline $\mathrm{T}_{2}$ & $5.397 \mathrm{fg}$ & $6.383 \mathrm{~cd}$ & $10.430 \mathrm{a}$ & $6.197 f$ & $7.183 \mathrm{~d}$ & $11.230 \mathrm{a}$ \\
\hline $\mathrm{T}_{3}$ & $3.783 \mathrm{i}-\mathrm{k}$ & $6.080 \mathrm{~d}-\mathrm{f}$ & $9.030 \mathrm{~b}$ & $4.583 \mathrm{ghi}$ & $6.880 \mathrm{de}$ & $9.830 \mathrm{~b}$ \\
\hline $\mathrm{T}_{4}$ & $3.440 \mathrm{j}-1$ & $5.570 \mathrm{e}-\mathrm{g}$ & $6.920 \mathrm{c}$ & $4.240 \mathrm{~h}-\mathrm{k}$ & $6.370 \mathrm{ef}$ & $7.720 \mathrm{c}$ \\
\hline $\mathrm{T}_{5}$ & $3.007 \mathrm{kl}$ & 4.310hi & $6.350 \mathrm{cde}$ & $3.807 \mathrm{jk}$ & $5.110 \mathrm{~g}$ & $7.150 \mathrm{~d}$ \\
\hline $\mathrm{T}_{6}$ & $1.787 \mathrm{no}$ & $3.340 \mathrm{jkl}$ & $3.587 \mathrm{i}-1$ & $2.587 \mathrm{~lm}$ & $4.140 \mathrm{~h}-\mathrm{k}$ & $4.387 \mathrm{~h}-\mathrm{j}$ \\
\hline $\mathrm{T}_{7}$ & $1.347 \mathrm{o}$ & $2.167 \mathrm{mn}$ & $3.227 \mathrm{j}-1$ & $2.147 \mathrm{~m}$ & 2.9671 & $4.027 \mathrm{i}-\mathrm{k}$ \\
\hline
\end{tabular}

Dry matter (g.m $\left.{ }^{-2}\right)$ :

Hybrid rice 1 registered the highest numerical value of dry matter yield and the lowest value was recorded by Sakha106 at late booting stage in both seasons as shown in Table 5. Concerning the dry matter yield at late booting stage in both seasons, significant differences were detected among the different sources treatments. $T_{2}$ treatment (anhydrous ammonia) was superior to all other treatments in dry matter yield while, the lowest value was recorded by $\mathrm{T}_{7}$ treatment (control) in both seasons. Rice cultivars and different sources of nitrogen application interaction was highly significant in season 2015 and 2016 as cleared in Table 6. Egyptian Hybrid ricel had the highest dry matter yield under $\mathrm{T}_{2}$ treatment, while Sakah106 recorded the lowest value under $T_{7}$ treatment in both seasons. The increases of such parameters in response to application of $\mathrm{N}$ fertilizers is probably due to enhancing availability of nitrogen which enhanced leaf area resulting in higher photo assimilates and thereby resulted in more dry matter accumulation. These findings confirm those of Alim, (2012), Chaturvedi, (2005)and Debiprasad, et al., (2010).

Plant height $(\mathrm{cm})$ at harvest:

Significant differences in plant height were observed among the cultivars (Table 6). Egyptian Hybrid rice1show the maximum plant height followed by Giza179. Plant height of rice cultivars also varied significant due to nitrogen fertilizer application (Table 6). Application full dose of anhydrous ammonia (T2) produced the highest plant height. Plant grown without nitrogen fertilizer had the lowest plant height. Significant variation of different treatments of nitrogen fertilizer and varieties were observed (Table 7). Among the treatments combination (V3T2) gave the highest value of plant height and lowest from V3T7. Increase in plant height due to nitrogen application could be attributed mainly to the role of nitrogen in the stimulation of cell division. The results are in conformity with those of Osman, et al., (2013), and Ismail, et al., (2013), who observed a significant effect of nitrogen on plant height. 
Table 5. dry matter as affected by the interaction between rice cultivars and different treatments of nitrogen application in 2015 and 2016 seasons.

\begin{tabular}{lcccccc}
\hline \multirow{2}{*}{$\begin{array}{l}\text { Nitrogen } \\
\text { Treatment }\end{array}$} & \multicolumn{5}{c}{ Cultivars } \\
\cline { 2 - 7 } & Sakha106 (V1) & Giza 179 (V2) & Hybrid 1(V3) & Sakha106 (V1) & Giza 179 (V2) & Hybrid 1(V3) \\
\cline { 2 - 7 } & \multicolumn{7}{c}{$\mathbf{2 0 1 5}$} & & & 2016 & \\
\hline $\mathrm{T}_{1}$ & $340.0 \mathrm{i}$ & $400.1 \mathrm{gh}$ & $520.1 \mathrm{~d}$ & $358.0 \mathrm{i}$ & $418.1 \mathrm{gh}$ & $538.1 \mathrm{~d}$ \\
$\mathrm{~T}_{2}$ & $619.9 \mathrm{bc}$ & $600.0 \mathrm{bc}$ & $720.0 \mathrm{a}$ & $637.9 \mathrm{bc}$ & $618.0 \mathrm{bc}$ & $738.0 \mathrm{a}$ \\
$\mathrm{T}_{3}$ & $480.0 \mathrm{~d}-\mathrm{f}$ & $480.0 \mathrm{~d}-\mathrm{f}$ & $640.0 \mathrm{~b}$ & $498.0 \mathrm{de}$ & $498.0 \mathrm{de}$ & $658.0 \mathrm{~b}$ \\
$\mathrm{~T}_{4}$ & $458.6 \mathrm{e}-\mathrm{g}$ & $460.0 \mathrm{e}-\mathrm{g}$ & $580.1 \mathrm{c}$ & $476.6 \mathrm{ef}$ & $478.0 \mathrm{ef}$ & $598.1 \mathrm{c}$ \\
$\mathrm{T}_{5}$ & $420.0 \mathrm{fg}$ & $460.0 \mathrm{e}-\mathrm{g}$ & $497.8 \mathrm{de}$ & $438.0 \mathrm{fg}$ & $478.0 \mathrm{ef}$ & $515.8 \mathrm{de}$ \\
$\mathrm{T}_{6}$ & $280.0 \mathrm{j}$ & $360.0 \mathrm{hi}$ & $420.0 \mathrm{fg}$ & $298.0 \mathrm{j}$ & $378.0 \mathrm{hi}$ & $438.0 \mathrm{fg}$ \\
$\mathrm{T}_{7}$ & $280.0 \mathrm{j}$ & $260.1 \mathrm{j}$ & $400.1 \mathrm{gh}$ & $298.0 \mathrm{j}$ & $278.1 \mathrm{j}$ & $418.1 \mathrm{gh}$ \\
\hline
\end{tabular}

Table 6. Plant height $/ \mathrm{cm}$, No. of tiller $/ \mathrm{m}^{2}$, No. of panicle $/ \mathrm{m}^{2}$ at harvest as affected by rice cultivars and different treatments of nitrogen application in 2015 and 2016 seasons.

\begin{tabular}{|c|c|c|c|c|c|c|}
\hline \multirow{2}{*}{ Treatments } & \multicolumn{2}{|c|}{ Plant height $/ \mathrm{cm}$ at harvest } & \multicolumn{2}{|c|}{ No. of tiller/m2 } & \multicolumn{2}{|c|}{ No. of panicle/m2 } \\
\hline & 2015 & 2016 & 2015 & 2016 & 2015 & 2016 \\
\hline \multicolumn{7}{|l|}{ Cultivars: } \\
\hline Sakha106 $\left(\mathrm{V}_{1}\right)$ & $91.85 \mathrm{c}$ & $94.85 \mathrm{e}$ & $616.8 \mathrm{c}$ & $625.8 \mathrm{c}$ & $521.2 \mathrm{c}$ & $530.2 c$ \\
\hline $\operatorname{Giza179}\left(\mathrm{V}_{2}\right)$ & $98.05 b$ & $101.05 b$ & $643.5 b$ & $652.5 b$ & $570.3 b$ & $579.3 b$ \\
\hline Hybrid 1 (V3) & $106.69 \mathrm{a}$ & $109.69 \mathrm{a}$ & $669.5 \mathrm{a}$ & $678.5 \mathrm{a}$ & $649.9 \mathrm{a}$ & $658.9 \mathrm{a}$ \\
\hline F. test & $* *$ & $* *$ & $* *$ & $* *$ & $* *$ & $* *$ \\
\hline \multicolumn{7}{|c|}{ Nitrogen Treatment: } \\
\hline $\mathrm{T}_{1}$ & $97.32 \mathrm{~d}$ & $100.32 d$ & $613.8 \mathrm{~d}$ & $622.8 \mathrm{~d}$ & $562.6 \mathrm{~d}$ & $571.6 \mathrm{~d}$ \\
\hline $\mathrm{T}_{2}$ & $106.33 \mathrm{a}$ & $109.33 a$ & $765.4 \mathrm{a}$ & $774.4 \mathrm{a}$ & $702.7 \mathrm{a}$ & $711.7 \mathrm{a}$ \\
\hline $\mathrm{T}_{3}$ & $101.83 b$ & $104.83 b$ & $688.1 \mathrm{~b}$ & $697.1 b$ & $625.3 b$ & $634.3 b$ \\
\hline $\mathrm{T}_{4}$ & $100.93 \mathrm{bc}$ & $103.93 b c$ & $674.7 b$ & $683.7 b$ & $614.7 b$ & $623.7 b$ \\
\hline $\mathrm{T}_{5}$ & $99.50 \mathrm{c}$ & $102.50 \mathrm{c}$ & $636.0 \mathrm{c}$ & $645.0 \mathrm{c}$ & $585.3 \mathrm{c}$ & $594.3 c$ \\
\hline $\mathrm{T}_{6}$ & $95.52 \mathrm{~d}$ & $98.52 d$ & $577.0 \mathrm{e}$ & $586.0 \mathrm{e}$ & $523.1 \mathrm{e}$ & $532.1 \mathrm{e}$ \\
\hline $\mathrm{T}_{7}$ & $90.61 \mathrm{e}$ & $93.61 \mathrm{e}$ & $548.0 \mathrm{f}$ & $557.0 \mathrm{f}$ & $449.3 \mathrm{f}$ & $458.3 \mathrm{f}$ \\
\hline F. test & $* *$ & $* *$ & $* *$ & $* *$ & $* *$ & $* *$ \\
\hline Interaction & $*$ & $*$ & $*$ & $*$ & $*$ & $*$ \\
\hline
\end{tabular}

Whereas:

$T_{1}$ : Recommended dose of $N$ as urea (165 kg N/ha), $T_{2}$ : Recommended dose of $N$ as Anhydrous Ammonia (165 kg N/ha), $T_{3}: 3 / 4$ dose of Anhydrous Ammonia $+1 / 4 \mathrm{~N}$ as urea at panicle initiation., $\mathrm{T}_{4}: 3 / 4$ dose of Anhydrous Ammonia $+1 / 4$ dose of $\mathrm{N}$ as urea at late booting, $\mathrm{T}_{5}: 1 / 2$ dose of $\mathrm{N}$ as Anhydrous Ammonia $+1 / 2 \mathrm{~N}$ as urea at panicle initiation, $\mathrm{T}_{6}: 1 / 2$ dose of $\mathrm{N}$ as Anhydrous Ammonia $+1 / 2 \mathrm{~N}$ as urea at late booting, $\mathrm{T}_{7}$ : Control (Zero Fertilizer).

Table 7. Plant height $/ \mathrm{cm}$ at harvest as affected by the interaction between rice cultivars and different treatments of nitrogen application in 2015 and 2016 seasons.

\begin{tabular}{|c|c|c|c|c|c|c|}
\hline \multirow{3}{*}{$\begin{array}{l}\text { Nitrogen } \\
\text { Treatment }\end{array}$} & \multicolumn{6}{|c|}{ Cultivars } \\
\hline & Sakha106 (V1) & Giza 179 (V2) & Hybrid 1(V3) & Sakha106(V1) & Giza 179 (V2) & Hybrid1(V3) \\
\hline & \multicolumn{3}{|c|}{2015} & \multicolumn{3}{|c|}{2016} \\
\hline $\mathrm{T}_{1}$ & $90.29 \mathrm{fg}$ & $94.84 \mathrm{e}$ & $106.83 b$ & 93.29hi & $97.84 f$ & $109.83 b c$ \\
\hline $\mathrm{T}_{2}$ & $100.84 d$ & $105.33 \mathrm{bc}$ & $112.84 \mathrm{a}$ & $103.84 \mathrm{e}$ & $108.33 b c$ & $115.84 \mathrm{a}$ \\
\hline $\mathrm{T}_{3}$ & $93.67 \mathrm{ef}$ & $104.50 \mathrm{bc}$ & $107.34 \mathrm{~b}$ & $96.67 \mathrm{fg}$ & $107.50 \mathrm{~cd}$ & $110.34 b$ \\
\hline $\mathrm{T}_{4}$ & 93.17ef & $102.50 \mathrm{~cd}$ & $107.11 \mathrm{~b}$ & $96.17 \mathrm{fg}$ & $105.50 \mathrm{de}$ & $110.11 b c$ \\
\hline $\mathrm{T}_{5}$ & $91.17 \mathrm{efg}$ & $100.34 d$ & $107.00 \mathrm{~b}$ & $94.17 \mathrm{gh}$ & $103.34 \mathrm{e}$ & $110.00 \mathrm{bc}$ \\
\hline $\mathrm{T}_{6}$ & $88.17 \mathrm{gh}$ & $93.00 \mathrm{ef}$ & $105.40 \mathrm{bc}$ & $91.17 \mathrm{ij}$ & $96.00 \mathrm{fg}$ & $108.40 \mathrm{bc}$ \\
\hline $\mathrm{T}_{7}$ & $85.67 \mathrm{~h}$ & $85.83 \mathrm{~h}$ & $100.33 d$ & $88.67 \mathrm{j}^{\circ}$ & $88.83 \mathrm{j}$ & $103.33 \mathrm{e}$ \\
\hline
\end{tabular}

Number of tiller $/ \mathrm{m}^{2}$ at harvest:

Number of tillers. $\mathrm{m}^{-2}$ varied significantly among by the cultivars (Table6). Data in Table 6 indicated that nitrogen fertilizer affected significantly number of tillers $\mathrm{m}^{-}$ 2. Number of tillers significantly increased in case of EHR1. Application of full dose of anhydrous ammonia $\left(T_{2}\right)$ produced the highest number of tillers. $\mathrm{m}^{-2}$ followed by the treatments $\left(\mathrm{T}_{3} \& \mathrm{~T}_{4}\right)$. Control treatment plant grown without nitrogen fertilizer had the lowest effective tillers. Similar results of applied $\mathrm{N}$ fertilizer were reported by Matsuo et al, 1995;who, reported that it is necessary to apply much $\mathrm{N}$ fertilizers to help rice plants to accelerate the phosphate absorption for increased tillering. Alim, 2012 found that the differences in the number of tillers among the different type and compatible $\mathrm{N}$ were mainly due to their variations in the availability of $\mathrm{N}$ and other nutrients. Adequacy of nitrogen probably favored the cellular activities during panicle formation and development that led to increased number of tillers. hill ${ }^{-1}$, consequently in the number of tillers. $\mathrm{m}^{-2}$. Regarding the interaction effect of rice cultivars and different sources of nitrogen fertilizers (Table 8), it is obviously clear that, the application of full dose of anhydrous ammonia $\left(\mathrm{T}_{2}\right)$ produced the highest number of tillrs.m ${ }^{-2}$ with Egyptian hybrid rice 1, followed by Giza 179 which gave the highest number of tillers under the same treatment of nitrogen application in this study.

\section{Number of panicle $/ \mathrm{m}^{2}$ at harvest:}

The highest value of number of panicle $/ \mathrm{m} 2$ at harvest was observed with EHR1 followed by Giza 179.Nitrogen application significantly affected the number of panicles. Maximum value of number of panicles was recorded when recommended dose of nitrogen as anhydrous ammonia was applied (T2)while, the lowest value was observed when nitrogen was not applied. This mainly due to the role of nitrogen in physiological process. These results 
are supported by the findings of Chaturvedi, 2005, who concluded that, the urea fertilizer show significant reductions in growth and yields in most of the experiments compared with ammonium nitrogen fertilizer form.

Table 8. No. of tiller at harvest $/ \mathrm{m}^{2}$ as affected by the interaction between rice cultivars and different treatments of nitrogen application in 2015 and 2016 seasons.

\begin{tabular}{|c|c|c|c|c|c|c|}
\hline \multirow{3}{*}{$\begin{array}{l}\text { Nitrogen } \\
\text { Treatment }\end{array}$} & \multicolumn{6}{|c|}{ Cultivars } \\
\hline & Sakha106(V1) & Giza 179 (V2) & Hybrid 1(V3) & Sakha106(V1) & Giza 179 (V2) & Hybrid 1 (V3) \\
\hline & \multicolumn{3}{|c|}{2015} & \multicolumn{3}{|c|}{2016} \\
\hline$\overline{\mathrm{T}_{1}}$ & $589.3 \mathrm{gh}$ & $628.1 \mathrm{ef}$ & $624.0 \mathrm{ef}$ & $598.3 \mathrm{ij}$ & $637.1 \mathrm{fgh}$ & 633.0gh \\
\hline $\mathrm{T}_{2}$ & $716.1 \mathrm{bc}$ & $748.0 \mathrm{~b}$ & $832.0 \mathrm{a}$ & $725.1 \mathrm{c}$ & $757.0 \mathrm{~b}$ & $841.0 \mathrm{a}$ \\
\hline $\mathrm{T}_{3}$ & $652.1 \mathrm{de}$ & $684.0 \mathrm{~cd}$ & $728.1 \mathrm{~b}$ & $661.1 \mathrm{efg}$ & $693.0 \mathrm{de}$ & $737.1 \mathrm{bc}$ \\
\hline $\mathrm{T}_{4}$ & 644.1ef & $660.0 \mathrm{de}$ & $720.0 b$ & $653.1 \mathrm{efg}$ & $669.0 \mathrm{e}-\mathrm{h}$ & $729.0 \mathrm{bc}$ \\
\hline $\mathrm{T}_{5}$ & $612.0 \mathrm{fg}$ & $640.1 \mathrm{ef}$ & $655.9 \mathrm{de}$ & 621.0hi & $649.1 \mathrm{ij}$ & 664.9def \\
\hline $\mathrm{T}_{6}$ & $572.1 \mathrm{hi}$ & 584.1ghi & 574.7hi & $581.1 \mathrm{jk}$ & $593.1 \mathrm{jkl}$ & $583.7 \mathrm{jk}$ \\
\hline $\mathrm{T}_{7}$ & $532.1 \mathrm{j}$ & 559.9hij & $552.0 \mathrm{ij}$ & 541.11 & $568.9 \mathrm{kl}$ & $561.0 \mathrm{kl}$ \\
\hline
\end{tabular}

Regarding the interaction effect of rice cultivars and panicles. $\mathrm{m}^{-2}$ with Egyptian hybrid rice1, followed by Giza different sources of nitrogen fertilizers (Table 9), it is 179 which gave the highest number of panicles under the obviously clear that the application of full dose of same treatment of nitrogen application under this study. anhydrous ammonia $\left(\mathrm{T}_{2}\right)$ produced the highest number of

Table 9. No. of panicle at harvest $/ \mathrm{m}^{2}$ as affected by the interaction between rice cultivars and different treatments of nitrogen application in 2015 and 2016 seasons.

\begin{tabular}{lcccccc}
\hline \multirow{2}{*}{$\begin{array}{l}\text { Nitrogen } \\
\text { Treatment }\end{array}$} & \multicolumn{5}{c}{ Cultivars } \\
\cline { 2 - 7 } & Sakha106(V1) & Giza 179 (V2) & Hybrid 1(V3) & Sakha106(V1) & Giza 179 (V2) & Hybrid 1(V3) \\
\cline { 2 - 7 } & $520.0 \mathrm{~h}$ & $563.9 \mathrm{efg}$ & $604.0 \mathrm{cde}$ & $529.0 \mathrm{~g}$ & $572.9 \mathrm{ef}$ & $613.0 \mathrm{~cd}$ \\
$\mathrm{~T}_{1}$ & $620.1 \mathrm{~cd}$ & $676.0 \mathrm{~b}$ & $811.9 \mathrm{a}$ & $629.1 \mathrm{~cd}$ & $685.0 \mathrm{~b}$ & $820.9 \mathrm{a}$ \\
$\mathrm{T}_{2}$ & $559.9 \mathrm{fgh}$ & $612.0 \mathrm{~cd}$ & $704.1 \mathrm{~b}$ & $568.9 \mathrm{ef}$ & $621.0 \mathrm{~cd}$ & $713.1 \mathrm{~b}$ \\
$\mathrm{~T}_{3}$ & $552.0 \mathrm{fgh}$ & $604.0 \mathrm{cde}$ & $688.0 \mathrm{~b}$ & $561.0 \mathrm{eg}$ & $613.0 \mathrm{~cd}$ & $697.0 \mathrm{~b}$ \\
$\mathrm{~T}_{4}$ & $536.1 \mathrm{gh}$ & $587.9 \mathrm{def}$ & $631.9 \mathrm{e}$ & $545.1 \mathrm{fg}$ & $596.9 \mathrm{de}$ & $640.9 \mathrm{c}$ \\
$\mathrm{T}_{5}$ & $476.1 \mathrm{i}$ & $528.0 \mathrm{gh}$ & $565.4 \mathrm{efg}$ & $485.1 \mathrm{~h}$ & $537.0 \mathrm{fg}$ & $574.4 \mathrm{ef}$ \\
$\mathrm{T}_{6}$ & $384.0 \mathrm{j}$ & $420.0 \mathrm{j}$ & $544.0 \mathrm{gh}$ & $393.0 \mathrm{j}$ & $429.0 \mathrm{i}$ & $553.0 \mathrm{fg}$ \\
$\mathrm{T}_{7}$ & & &
\end{tabular}

\section{Panicle weight (g):}

Panicle weight differed significantly in all cultivars (Table 10). The maximum panicle weight was observed with EHR1 followed by Giza179. There were a significant differences in panicle weight among different nitrogen sources treatments. Where, $\mathrm{T}_{2}$ treatment (anhydrous ammonia) produced the heaviest panicle weight, while $\mathrm{T}_{7}$ treatment (control) produced the lowest value of panicle weight in both seasons.

The interaction between rice cultivars and different sources of nitrogen was highly significant in both seasons of study 2015 and 2016. Data in Table (11) recorded that, under $\mathrm{T}_{2}$ treatment, EHR1 produced the heaviest panicle weight, while the lowest value of panicle weight was recorded under $T_{7}$ treatment. Thus, the increase in growth and yield owing to the application of $\mathrm{N}$-fertilizers may be attributed to the fact that these nutrients being important constituents of nucleotides, proteins, chlorophyll and enzymes, involve in various metabolic processes which have direct impact on vegetative and reproductive phases of plants. These findings confirm those of Chaturvedi,2005who concluded that, without fertilizer gave the lowest grain $\mathrm{N}$ content in experiments. Thus,it may be concluded that nitrogen fertilizer was found to be optimum for rice production.

Table 10. Panicle weight (g) and panicle length $(\mathrm{cm})$ as affected by rice cultivars and different treatments of nitrogen application in 2015 and 2016 seasons.

\begin{tabular}{|c|c|c|c|c|}
\hline \multirow{2}{*}{ Treatments } & \multicolumn{2}{|c|}{ Panicle weight (g) } & \multicolumn{2}{|c|}{ Panicle length $(\mathrm{cm})$} \\
\hline & 2015 & 2016 & 2015 & 2016 \\
\hline Cultivars: & & & & \\
\hline Sakha106 $\left(\mathrm{V}_{1}\right)$ & $3.133 b$ & $3.173 b$ & $20.279 b$ & $20.389 b$ \\
\hline Giza179 $\left(\mathrm{V}_{2}\right)$ & $3.364 \mathrm{a}$ & $3.404 \mathrm{a}$ & $20.836 \mathrm{ab}$ & $20.946 a b$ \\
\hline Hybrid 1 (V3) & $3.477 \mathrm{a}$ & $3.517 \mathrm{a}$ & $21.364 \mathrm{a}$ & $21.474 \mathrm{a}$ \\
\hline F. test & $*$ & $*$ & $*$ & $*$ \\
\hline Nitrogen Treatment: & & & & \\
\hline $\mathrm{T}_{1}$ & $3.362 \mathrm{c}$ & $3.402 \mathrm{c}$ & $20.433 c$ & $20.543 c$ \\
\hline $\mathrm{T}_{2}$ & $3.957 \mathrm{a}$ & $3.997 \mathrm{a}$ & $22.700 \mathrm{a}$ & $22.810 \mathrm{a}$ \\
\hline $\mathrm{T}_{3}$ & $3.660 \mathrm{~b}$ & $3.700 \mathrm{~b}$ & $22.117 b$ & $22.227 \mathrm{~b}$ \\
\hline $\mathrm{T}_{4}$ & $3.546 \mathrm{bc}$ & $3.586 \mathrm{bc}$ & $21.817 \mathrm{~b}$ & $21.927 \mathrm{~b}$ \\
\hline $\mathrm{T}_{5}$ & $3.330 \mathrm{c}$ & $3.370 \mathrm{c}$ & $20.800 \mathrm{c}$ & $20.910 \mathrm{c}$ \\
\hline $\mathrm{T}_{6}$ & $2.907 \mathrm{~d}$ & $2.947 \mathrm{~d}$ & $19.817 \mathrm{~d}$ & $19.927 \mathrm{~d}$ \\
\hline $\mathrm{T}_{7}$ & $2.510 \mathrm{e}$ & $2.550 \mathrm{e}$ & $18.100 \mathrm{e}$ & $18.210 \mathrm{e}$ \\
\hline F. test & $* *$ & $* *$ & $* *$ & $* *$ \\
\hline Interaction & $*$ & $*$ & $*$ & $*$ \\
\hline
\end{tabular}

\section{Whereas:}

$T_{1}$ : Recommended dose of $N$ as urea (165 kg N/ha), $T_{2}$ : Recommended dose of $N$ as Anhydrous Ammonia (165 kg N/ha), $T_{3}: 3 / 4$ dose of Anhydrous Ammonia $+1 / 4 \mathrm{~N}$ as urea at panicle initiation., $\mathrm{T}_{4}: 3 / 4$ dose of Anhydrous Ammonia $+1 / 4$ dose of $\mathrm{N}$ as urea at late booting, $\mathrm{T}_{5}: 1 / 2 \mathrm{dose}$ of $\mathrm{N}$ as Anhydrous Ammonia $+1 / 2 \mathrm{~N}$ as urea at panicle initiation, $T_{6}: 1 / 2$ dose of $\mathrm{N}$ as Anhydrous Ammonia $+1 / 2 \mathrm{~N}$ as urea at late booting, $\mathrm{T}_{7}$ : Control (Zero Fertilizer). 
Table 11. Panicle weight (g) as affected by the interaction between rice cultivars and different treatments of nitrogen application in 2015 and 2016 seasons.

\begin{tabular}{|c|c|c|c|c|c|c|}
\hline \multirow{3}{*}{$\begin{array}{l}\text { Nitrogen } \\
\text { Treatment }\end{array}$} & \multicolumn{6}{|c|}{ Cultivars } \\
\hline & Sakha106 (V1) & Giza 179 (V2) & Hybrid 1 (V3) & Sakha106 (V1) & Giza 179 (V2) & Hybrid 1 (V3) \\
\hline & \multicolumn{3}{|c|}{2015} & \multicolumn{3}{|c|}{2016} \\
\hline$\overline{\mathrm{T}_{1}}$ & $3.000 \mathrm{f}-\mathrm{i}$ & $3.747 \mathrm{bc}$ & $3.340 \mathrm{c}-\mathrm{f}$ & 3.040ghi & $3.787 b c$ & 3.380def \\
\hline $\mathrm{T}_{2}$ & $3.740 \mathrm{bc}$ & $3.830 \mathrm{~b}$ & $4.300 \mathrm{a}$ & $3.780 \mathrm{bc}$ & $3.870 \mathrm{~b}$ & $4.340 \mathrm{a}$ \\
\hline $\mathrm{T}_{3}$ & $3.420 \mathrm{~b}-\mathrm{f}$ & $3.730 \mathrm{bc}$ & $3.830 \mathrm{~b}$ & $3.460 \mathrm{cde}$ & $3.770 \mathrm{bc}$ & $3.870 \mathrm{~b}$ \\
\hline $\mathrm{T}_{4}$ & $3.220 \mathrm{e}-\mathrm{g}$ & $3.620 \mathrm{~b}-\mathrm{e}$ & $3.797 b$ & $3.260 \mathrm{efg}$ & $3.660 \mathrm{bcd}$ & $3.837 \mathrm{~b}$ \\
\hline $\mathrm{T}_{5}$ & $3.040 \mathrm{f}-\mathrm{i}$ & $3.280 \mathrm{def}$ & $3.670 \mathrm{~b}-\mathrm{d}$ & $3.080 \mathrm{fgh}$ & $3.320 \mathrm{efg}$ & $3.710 \mathrm{bc}$ \\
\hline $\mathrm{T}_{6}$ & $2.810 \mathrm{~g}-\mathrm{j}$ & 2.770hij & $3.140 \mathrm{fgh}$ & $2.850 \mathrm{hij}$ & 2.810hij & $3.180 \mathrm{efg}$ \\
\hline $\mathrm{T}_{7}$ & $2.700 \mathrm{ij}$ & $2.570 \mathrm{jk}$ & $2.260 \mathrm{k}$ & $2.740 \mathrm{ij}$ & $2.610 \mathrm{j}^{\circ}$ & $2.300 \mathrm{k}$ \\
\hline
\end{tabular}

\section{Panicle length (cm):}

Cultivars show significant variation in respect of panicle length (Table 10). The longest panicle was observed from EHR1 and the shortest from Sakha106. Nitrogen had significant role in increasing the panicle length (Table 10). Concerning the panicle length there was a significant difference were detected among different sources of treatments in both seasons. $T_{2}$ treatment (anhydrous ammonia) produced the longest panicle, while $\mathrm{T}_{7}$ treatment (control) produced the shortest panicle length in both seasons. Similar results were reported for lowland rice by Sahar and Burbey (2003), Osman, et al., (2013) and Chaturvedi, (2005). Data in Table 12 showed that a significant interaction between rice cultivars and different nitrogen sources in panicle length $(\mathrm{cm})$ in both seasons of study. Data revealed that EHR1produced the highest panicles length (cm) in both seasons when treated with application recommended dose of anhydrous ammonia $\left(\mathrm{T}_{2}\right)$. On the other hand, Giza179 gave nearly the lowest panicles length which non-treated with any nitrogen treatment under this study.

Table 12. Panicle length $(\mathrm{cm})$ as affected by the interaction between rice cultivars and different treatments of nitrogen application in 2015 and 2016 seasons.

\begin{tabular}{lcccccc}
\hline \multirow{2}{*}{$\begin{array}{l}\text { Nitrogen } \\
\text { Treatment }\end{array}$} & \multicolumn{5}{c}{ Cultivars } \\
\cline { 2 - 7 } & Sakha106 (V1) & Giza 179(V2) & Hybrid 1 (V3) & Sakha106 (V1) & Giza 179 (V2) & Hybrid 1(V3) \\
\cline { 2 - 7 } & $19.900 \mathrm{ef}$ & $20.400 \mathrm{de}$ & $21.000 \mathrm{~cd}$ & $20.010 \mathrm{hi}$ & $20.510 \mathrm{fgh}$ & $21.110 \mathrm{def}$ \\
$\mathrm{T}_{1}$ & $21.500 \mathrm{c}$ & $23.150 \mathrm{ab}$ & $23.450 \mathrm{a}$ & $21.610 \mathrm{~d}$ & $23.260 \mathrm{ab}$ & $23.560 \mathrm{a}$ \\
$\mathrm{T}_{2}$ & $21.200 \mathrm{~cd}$ & $22.550 \mathrm{~b}$ & $22.600 \mathrm{~b}$ & $21.310 \mathrm{de}$ & $22.660 \mathrm{c}$ & $22.710 \mathrm{bc}$ \\
$\mathrm{T}_{3}$ & $20.700 \mathrm{cde}$ & $22.350 \mathrm{~b}$ & $22.400 \mathrm{~b}$ & $20.810 \mathrm{efg}$ & $22.460 \mathrm{c}$ & $22.510 \mathrm{c}$ \\
$\mathrm{T}_{4}$ & $20.350 \mathrm{de}$ & $21.000 \mathrm{~cd}$ & $21.050 \mathrm{~cd}$ & $20.460 \mathrm{gh}$ & $21.110 \mathrm{def}$ & $21.160 \mathrm{de}$ \\
$\mathrm{T}_{5}$ & $19.550 \mathrm{f}$ & $19.250 \mathrm{fg}$ & $20.650 \mathrm{cde}$ & $19.660 \mathrm{ij}$ & $19.360 \mathrm{jk}$ & $20.760 \mathrm{efg}$ \\
$\mathrm{T}_{6}$ & $18.750 \mathrm{gh}$ & $17.150 \mathrm{i}$ & $18.400 \mathrm{~h}$ & $18.860 \mathrm{kl}$ & $17.260 \mathrm{~m}$ & 18.5101 \\
$\mathrm{~T}_{7}$ & & &
\end{tabular}

Filled grain and unfilled grains/ panicle:

Filled grain and unfilled grain per panicle variations exerted significant influence on the filled grain. panicle ${ }^{-1}$ (Table 13). Cultivar EHR1 produced the maximum number of filled grains panicle ${ }^{-1}$ followed by Giza179. The lowest number of filled grain panicle ${ }^{-1}$ was observed from Sakha106. Also, data showed that the highest number of unfilled grain was observed with EHR1 while the lowest unfilled grain/ panicle was recorded by Sakha106. Filled as well as unfilled grains panicle $^{-1}$ was also significantly affected by different treatments in both seasons (Table 13). Full dose of anhydrous ammonia before flooded $\left(\mathrm{T}_{2}\right)$ introduced the highest number of filled grain panicle ${ }^{-1}$ followed by the treatment of $3 / 4$ anhydrous ammonia $+1 / 4$ urea at P.I $\left(\mathrm{T}_{3}\right)$. Control treatment produced the lowest number of filled grains. In this study, it was observed that the highest number of unfilled grain was produced with $1 / 2$ anhydrous ammonia $+1 / 2$ urea at late booting $\left(\mathrm{T}_{6}\right)$ due to applied half dose of urea at late booting which produced highest number of unfilled grain/panicle.The findings are in agreement with those of Chaturvedi, (2005)and Debiprasad, et al., (2010).

Table 13. No. of filled grain/panicle, No. of unfilled grain/panicle, 1000-grain weight as affected by rice cultivars and different treatments of nitrogenapplication in 2015 and 2016 seasons.

\begin{tabular}{|c|c|c|c|c|c|c|}
\hline \multirow{2}{*}{ Treatments } & \multicolumn{2}{|c|}{ No. of filled grain/panicle } & \multicolumn{2}{|c|}{ No. of unfilled grain/panicle } & \multicolumn{2}{|c|}{ 1000-grain weight (g) } \\
\hline & 2015 & 2016 & 2015 & 2016 & 2015 & 2016 \\
\hline \multicolumn{7}{|l|}{ Cultivars: } \\
\hline Sakha106 $\left(\mathrm{V}_{1}\right)$ & $105.99 \mathrm{c}$ & $108.99 \mathrm{c}$ & $3.300 \mathrm{c}$ & $5.300 \mathrm{c}$ & $27.619 a$ & $28.619 a$ \\
\hline Giza179 $\left(\mathrm{V}_{2}\right)$ & $117.10 \mathrm{~b}$ & $120.10 b$ & $4.600 \mathrm{~b}$ & $6.600 \mathrm{~b}$ & $24.286 \mathrm{c}$ & $25.286 \mathrm{c}$ \\
\hline Hybrid 1 (V3) & $136.00 \mathrm{a}$ & $139.00 \mathrm{a}$ & $5.943 \mathrm{a}$ & $7.943 \mathrm{a}$ & $23.857 \mathrm{~b}$ & $24.918 b$ \\
\hline F. test & $* *$ & $* *$ & $* *$ & $* *$ & $* *$ & $* *$ \\
\hline \multicolumn{7}{|l|}{ Nitrogen Treatment: } \\
\hline $\mathrm{T}_{1}$ & $110.27 \mathrm{~d}$ & $113.27 \mathrm{~d}$ & $3.433 \mathrm{e}$ & $5.433 \mathrm{e}$ & $26.278 b c$ & $27.278 \mathrm{bc}$ \\
\hline $\mathrm{T}_{2}$ & $145.74 \mathrm{a}$ & $148.74 \mathrm{a}$ & $5.667 \mathrm{~b}$ & $7.667 \mathrm{~b}$ & $23.000 \mathrm{f}$ & $24.000 \mathrm{f}$ \\
\hline $\mathrm{T}_{3}$ & $134.60 b$ & $137.60 \mathrm{~b}$ & $4.600 \mathrm{c}$ & $6.600 c$ & $24.667 \mathrm{e}$ & $25.667 \mathrm{e}$ \\
\hline $\mathrm{T}_{4}$ & $132.13 b$ & $135.13 b$ & $4.167 \mathrm{~cd}$ & $6.167 \mathrm{~cd}$ & $25.333 d$ & $26.333 d$ \\
\hline $\mathrm{T}_{5}$ & $122.97 \mathrm{c}$ & $125.97 \mathrm{c}$ & $3.833 \mathrm{de}$ & $5.833 \mathrm{de}$ & $25.833 \mathrm{~cd}$ & $26.833 \mathrm{~cd}$ \\
\hline $\mathrm{T}_{6}$ & $103.70 \mathrm{e}$ & $106.70 \mathrm{e}$ & $8.167 \mathrm{a}$ & $10.167 \mathrm{a}$ & $26.833 \mathrm{ab}$ & $27.833 \mathrm{ab}$ \\
\hline $\mathrm{T}_{7}$ & $88.47 \mathrm{f}$ & $91.47 \mathrm{f}$ & $2.433 \mathrm{f}$ & $4.433 \mathrm{f}$ & $27.170 \mathrm{a}$ & $28.140 \mathrm{a}$ \\
\hline F. test & $* *$ & $* *$ & $* *$ & $* *$ & $* *$ & $* *$ \\
\hline Interaction & $*$ & $*$ & $*$ & $*$ & $*$ & $*$ \\
\hline
\end{tabular}

$T_{1}$ : Recommended dose of $N$ as urea (165 kg N/ha), $T_{2}$ : Recommended dose of $N$ as Anhydrous Ammonia (165 kg N/ha), $T_{3}: 3 / 4$ dose of Anhydrous Ammonia $+1 / 4 \mathrm{~N}$ as urea at panicle initiation., $\mathrm{T}_{4}: 3 / 4$ dose of Anhydrous Ammonia $+1 / 4$ dose of $\mathrm{N}$ as urea at late booting, $\mathrm{T}_{5}: 1 / 2$ dose of $\mathrm{N}$ as Anhydrous Ammonia $+1 / 2 \mathrm{~N}$ as urea at panicle initiation, $T_{6}: 1 / 2$ dose of $\mathrm{N}$ as Anhydrous Ammonia $+1 / 2 \mathrm{~N}$ as urea at late booting, $\mathrm{T}_{7}$ : Control (Zero Fertilizer). 
Interaction between cultivars and nitrogen treatments significantly affected the number of filled and unfilled grains panicle ${ }^{-1}$ (Table14 and 15). The cultivarEHR1coupled with application full dose of anhydrous ammonia before flooded $\left(\mathrm{T}_{2}\right)$ introduced the highest number of filled grains panicle ${ }^{-1}$. The lowest number of filled grain, however produced by the treatment $V_{3} T_{7}$. This is might be due to larger panicle size and translocation of photosynthesis to the respiration organs for setting grains. The highest unfilled grains panicle ${ }^{-1}$ was found in with the combination of $\mathrm{V}_{3} \mathrm{~T}_{6}$ with no any significantly with $\mathrm{V}_{2} \mathrm{~T}_{6}$. This was mainly due to the lack of nitrogen's as it is a limiting nutrient factor for grain filling.

Table 14. No. of filled grain/panicle as affected by the interaction between rice cultivars and different treatments of nitrogen application in 2015 and 2016 seasons.

\begin{tabular}{|c|c|c|c|c|c|c|}
\hline \multirow{3}{*}{$\begin{array}{l}\text { Nitrogen } \\
\text { Treatment }\end{array}$} & \multicolumn{6}{|c|}{ Cultivars } \\
\hline & Sakha106 (V1) & Giza 179 (V2) & Hybrid 1(V3) & Sakha106 (V1) & Giza 179 (V2) & Hybrid 1(V3) \\
\hline & \multicolumn{3}{|c|}{2015} & \multicolumn{3}{|c|}{2016} \\
\hline$\overline{\mathrm{N}_{1}}$ & $100.50 \mathrm{jk}$ & $105.50 \mathrm{ij}$ & $124.80 \mathrm{efg}$ & $103.50 \mathrm{ij}$ & 108.50hi & $127.80 \mathrm{de}$ \\
\hline $\mathrm{N}_{2}$ & $128.50 \mathrm{ef}$ & $143.20 \mathrm{~d}$ & $165.53 \mathrm{a}$ & $131.50 \mathrm{~d}$ & $146.20 \mathrm{c}$ & $168.53 \mathrm{a}$ \\
\hline $\mathrm{N}_{3}$ & 115.00ghi & $132.50 \mathrm{e}$ & $156.30 \mathrm{ab}$ & $118.00 \mathrm{fg}$ & $135.50 \mathrm{~d}$ & $159.30 \mathrm{~b}$ \\
\hline $\mathrm{N}_{4}$ & $111.80 \mathrm{hi}$ & $129.60 \mathrm{ef}$ & $155.00 \mathrm{bc}$ & $114.80 \mathrm{gh}$ & $132.60 \mathrm{~d}$ & $158.00 \mathrm{~b}$ \\
\hline $\mathrm{N}_{5}$ & $105.60 \mathrm{ij}$ & $117.10 \mathrm{gh}$ & $146.20 \mathrm{~cd}$ & 108.60hi & $120.10 \mathrm{efg}$ & $149.20 \mathrm{c}$ \\
\hline $\mathrm{N}_{6}$ & $92.00 \mathrm{klm}$ & $98.50 \mathrm{jkl}$ & $120.60 \mathrm{fgh}$ & $95.00 \mathrm{kl}$ & $101.50 \mathrm{ijk}$ & $123.60 \mathrm{ef}$ \\
\hline $\mathrm{N}_{7}$ & $88.501 \mathrm{~m}$ & $93.30 \mathrm{klm}$ & $83.60 \mathrm{~m}$ & $91.501 \mathrm{~m}$ & $96.30 \mathrm{jkl}$ & $86.60 \mathrm{~m}$ \\
\hline
\end{tabular}

Table 15. No. of unfilled grain/panicle as affected by the interaction between rice cultivars and different treatments of nitrogen application in 2015 and 2016 seasons.

\begin{tabular}{|c|c|c|c|c|c|c|}
\hline \multirow{3}{*}{$\begin{array}{l}\text { Nitrogen } \\
\text { Treatment }\end{array}$} & \multicolumn{6}{|c|}{ Cultivars } \\
\hline & Sakha106 (V1) & Giza 179 (V2) & Hybrid 1(V3) & Sakha106 (V1) & Giza 179 (V2) & Hybrid 1(V3) \\
\hline & \multicolumn{3}{|c|}{2015} & \multicolumn{3}{|c|}{2016} \\
\hline $\mathrm{N}_{1}$ & $2.500 \mathrm{hi}$ & $3.500 \mathrm{fgh}$ & $4.300 \mathrm{efg}$ & 4.500ghi & $5.500 \mathrm{efg}$ & $6.300 \mathrm{e}$ \\
\hline $\mathrm{N}_{2}$ & $4.000 \mathrm{fg}$ & $5.500 \mathrm{cde}$ & $7.500 \mathrm{~b}$ & $6.000 \mathrm{ef}$ & $7.500 \mathrm{~cd}$ & $9.500 \mathrm{~b}$ \\
\hline $\mathrm{N}_{3}$ & $3.500 \mathrm{fgh}$ & $4.500 \mathrm{def}$ & $5.800 \mathrm{~cd}$ & $5.500 \mathrm{efg}$ & $6.500 \mathrm{de}$ & $7.800 \mathrm{c}$ \\
\hline $\mathrm{N}_{4}$ & $3.000 \mathrm{gh}$ & $4.000 \mathrm{fg}$ & $5.500 \mathrm{cde}$ & $5.000 \mathrm{fgh}$ & $6.000 \mathrm{ef}$ & $7.500 \mathrm{~cd}$ \\
\hline $\mathrm{N}_{5}$ & $2.500 \mathrm{hi}$ & $3.500 \mathrm{fgh}$ & $5.500 \mathrm{cde}$ & $4.500 \mathrm{ghi}$ & $5.500 \mathrm{efg}$ & $7.500 \mathrm{~cd}$ \\
\hline $\mathrm{N}_{6}$ & $6.000 \mathrm{c}$ & $9.000 \mathrm{a}$ & $9.500 \mathrm{a}$ & $8.000 \mathrm{c}$ & $11.00 \mathrm{a}$ & $11.500 \mathrm{a}$ \\
\hline $\mathrm{N}_{7}$ & $1.600 \mathrm{i}$ & $2.200 \mathrm{hi}$ & $3.500 \mathrm{fgh}$ & $3.600 \mathrm{i}$ & 4.200hi & $5.500 \mathrm{efg}$ \\
\hline
\end{tabular}

\section{0-grain weight:}

Cultivars showed significant response on 1000grain weight (Table 13). The highest 1000 -grain weight was observed with Sakha106 which was significantly higher than other cultivars. EHR1 showed the lowest 1000-grain weight. Nitrogen sources treatments influenced significantly the thousand grain weight. Maximum 1000-grain weight was recorded without application of nitrogen $\left(\mathrm{T}_{7}\right)$ and it was statistically at par with application $1 / 2$ of nitrogen as anhydrous ammonia $+1 / 2$ of nitrogen as urea at late booting $\left(\mathrm{T}_{6}\right)$. Which was superior over rest of the treatments. Mehla and Panwar (2001) also, observed differences in yield components and yield of different basmati rice cultivars. Similar results were reported earlier by Boli et al., (1995). Increase in 1000-grain weight with application full dose of anhydrous ammonia before flooded might be primarily due to higher photosynthetic rate and ultimately plenty of photosynthesis available during grain development (Kausar et al., 1993).Data in Table 16revealed that a significant difference on the interaction between rice cultivars and different nitrogen sources were recorded in both seasons. Data indicate that Sakha 106 gave the maximum 1000-grain weight which recorded without application of nitrogen $\left(\mathrm{T}_{7}\right)$ and it was statistically at par with application $1 / 2$ of nitrogen as anhydrous ammonia $+1 / 2$ of nitrogen as urea at late booting $\left(\mathrm{T}_{6}\right)$.

Table 16. 1000-grain weight as affected by the interaction between rice cultivars and different treatments of nitrogen application in 2015 and 2016 seasons.

\begin{tabular}{lcccccc}
\hline \multirow{2}{*}{$\begin{array}{l}\text { Nitrogen } \\
\text { Treatment }\end{array}$} & Sakha106 (V1) & Giza 179 (V2) & Hybrid 1 (V3) & Sakha106 (V1) & Giza 179 (V2) & Hybrid 1 (V3) \\
\cline { 2 - 7 } & \multicolumn{5}{c}{$\mathbf{2 0 1 5}$} \\
\cline { 2 - 6 } & $27.833 \mathrm{~b}$ & $26.500 \mathrm{cde}$ & $24.500 \mathrm{ghi}$ & $28.833 \mathrm{~b}$ & $27.500 \mathrm{cde}$ & $25.500 \mathrm{ghi}$ \\
$\mathrm{T}_{1}$ & $25.500 \mathrm{efg}$ & 21.5001 & $22.000 \mathrm{kl}$ & $26.500 \mathrm{efg}$ & 22.5001 & $23.000 \mathrm{kl}$ \\
$\mathrm{T}_{2}$ & $27.000 \mathrm{bcd}$ & $24.000 \mathrm{hij}$ & $23.000 \mathrm{jk}$ & $28.000 \mathrm{bcd}$ & $25.000 \mathrm{hij}$ & $24.000 \mathrm{jk}$ \\
$\mathrm{T}_{3}$ & $27.500 \mathrm{bc}$ & $25.000 \mathrm{fgh}$ & $23.500 \mathrm{ij}$ & $28.500 \mathrm{bc}$ & $26.000 \mathrm{fgh}$ & $24.500 \mathrm{ij}$ \\
$\mathrm{T}_{4}$ & $27.500 \mathrm{bc}$ & $26.000 \mathrm{def}$ & $24.000 \mathrm{hij}$ & $28.500 \mathrm{bc}$ & $27.000 \mathrm{def}$ & $25.000 \mathrm{hij}$ \\
$\mathrm{T}_{5}$ & $29.000 \mathrm{a}$ & $26.500 \mathrm{cde}$ & $25.000 \mathrm{fgh}$ & $30.000 \mathrm{a}$ & $27.500 \mathrm{cde}$ & $26.000 \mathrm{fgh}$ \\
$\mathrm{T}_{6}$ & $29.000 \mathrm{a}$ & $27.000 \mathrm{bcd}$ & $25.500 \mathrm{efg}$ & $30.000 \mathrm{a}$ & $28.000 \mathrm{bcd}$ & $26.430 \mathrm{efg}$ \\
$\mathrm{T}_{7}$ & & & &
\end{tabular}

Grain and straw yield:

The rice cultivars different significantly in respect of grain and straw yield ha-1 (Table 17). The hybrid rice cultivar produced the highest grain and straw yield followed by Giza179. The results were in conformity with the observation of Mariam, (2007) and Bijesh Maharjan and Rodney T. Venterea (2014). Grain and straw yield t. ha ${ }^{-1}$ increased with applying nitrogen 
as full dose in the form of anhydrous ammonia injection into soil before flooded. Application of anhydrous ammonia injection in soil before flooded $\left(\mathrm{T}_{2}\right)$ gave the maximum grain and straw yield followed by $\left(\mathrm{T}_{3}\right) 3 / 4$ of nitrogen as anhydrous ammonia $+1 / 4$ nitrogen as urea at panicle initiation (P.I) which was statistically at par with $\left(\mathrm{T}_{4}\right) 3 / 4$ of nitrogen as anhydrous ammonia $+1 / 4$ nitrogen as urea at late booting (LB) in the two seasons. High yield of application anhydrous ammonia injection in soil before flooded $\left(\mathrm{T}_{2}\right)$ might be primarily due to more filled grains and high value of the panicle weight. The interaction effect of rice cultivars and nitrogen sources exerted significant influence on the grain and straw yield (Table 18 and19) combination of $\mathrm{V}_{3} \mathrm{~T}_{2}$ produced the highest grain and straw yield and it was statistically identical with $\mathrm{V}_{3} \mathrm{~T}_{3}, \mathrm{~V}_{3} \mathrm{~T}_{4}, \mathrm{~V}_{2} \mathrm{~T}_{2}$ and $\mathrm{V}_{2} \mathrm{~T}_{3}$ in both seasons of study. It was observed that the lowest values of grain yield were produced with $\mathrm{T}_{7}$ (without $\mathrm{N}$ ) application with all cultivars. This may be due to low soil nitrogen contents that would delay root growth and ultimately crop establishment. Andrews. (1956), Chaturvedi, (2005), Debiprasad, et al., (2010)and Osman, et al., (2013) concluded that the grain and straw of rice yield were increased significantly by adding nitrogen fertilizer. Yield ofrice grain was increased significantly when $\mathrm{N}$ fertilizer at $220 \mathrm{~kg} / \mathrm{ha}$ was added, while the lowest value was recorded by control treatment (without addition of $\mathrm{N}$ fertilizer).
Table 17. Grain yield and straw yield t/ha as affected by rice cultivars and different treatments of nitrogen application in 2015 and 2016 seasons.

\begin{tabular}{lcccc}
\hline \multirow{2}{*}{ Treatments } & \multicolumn{2}{c}{ Grain yield t/ha } & \multicolumn{2}{c}{ Straw yield t/ha } \\
\cline { 2 - 5 } & $\mathbf{2 0 1 5}$ & $\mathbf{2 0 1 6}$ & $\mathbf{2 0 1 5}$ & $\mathbf{2 0 1 6}$ \\
\hline Cultivars: & & & & \\
Sakha106 $\left(\mathrm{V}_{1}\right)$ & $10.850 \mathrm{c}$ & $11.080 \mathrm{c}$ & $11.810 \mathrm{~b}$ & $12.040 \mathrm{~b}$ \\
Giza179 $\left(\mathrm{V}_{2}\right)$ & $11.310 \mathrm{~b}$ & $11.540 \mathrm{~b}$ & $12.233 \mathrm{~b}$ & $12.463 \mathrm{~b}$ \\
Hybrid 1 (V3) & $11.678 \mathrm{a}$ & $11.908 \mathrm{a}$ & $13.303 \mathrm{a}$ & $13.533 \mathrm{a}$ \\
\hline F. test & $* *$ & $* *$ & $* *$ & $* *$ \\
\hline
\end{tabular}

Nitrogen Treatment:

\begin{tabular}{lcccc}
$\mathrm{T}_{1}$ & $11.436 \mathrm{~d}$ & $11.703 \mathrm{~d}$ & $12.193 \mathrm{~d}$ & $12.423 \mathrm{~d}$ \\
$\mathrm{~T}_{2}$ & $12.472 \mathrm{a}$ & $12.437 \mathrm{a}$ & $13.760 \mathrm{a}$ & $13.990 \mathrm{a}$ \\
$\mathrm{T}_{3}$ & $12.161 \mathrm{~b}$ & $12.387 \mathrm{~b}$ & $13.357 \mathrm{~b}$ & $13.587 \mathrm{~b}$ \\
$\mathrm{~T}_{4}$ & $12.003 \mathrm{bc}$ & $12.211 \mathrm{bc}$ & $13.106 \mathrm{bc}$ & $13.336 \mathrm{~b}$ \\
$\mathrm{~T}_{5}$ & $11.752 \mathrm{c}$ & $12.073 \mathrm{c}$ & $12.783 \mathrm{c}$ & $13.013 \mathrm{c}$ \\
$\mathrm{T}_{6}$ & $11.221 \mathrm{~d}$ & $11.413 \mathrm{~d}$ & $12.078 \mathrm{~d}$ & $12.308 \mathrm{~d}$ \\
$\mathrm{~T}_{7}$ & $7.910 \mathrm{e}$ & $8.140 \mathrm{e}$ & $9.864 \mathrm{e}$ & $10.094 \mathrm{e}$ \\
\hline F. test & $* *$ & $* *$ & $* *$ & $* *$ \\
\hline Interaction & $* *$ & $* *$ & $* *$ & $* *$
\end{tabular}

Whereas:

$T_{1}$ : Recommended dose of $\mathrm{N}$ as urea $(165 \mathrm{~kg} \mathrm{~N} / \mathrm{ha}), \mathrm{T}_{2}$ : Recommended dose of $\mathrm{N}$ as Anhydrous Ammonia (165 kg N/ha), $\mathrm{T}_{3}: 3 / 4$ dose of Anhydrous Ammonia $+1 / 4 \mathrm{~N}$ as urea at panicle initiation., $T_{4}: 3 / 4$ dose of Anhydrous Ammonia $+1 / 4$ dose of $N$ as urea at late booting, $T_{5}: 1 / 2$ dose of $\mathrm{N}$ as Anhydrous Ammonia $+1 / 2 \mathrm{~N}$ as urea at panicle initiation, $T_{6}: 1 / 2$ dose of $N$ as Anhydrous Ammonia $+1 / 2 \mathrm{~N}$ as urea at late booting, $\mathrm{T}_{7}$ : Control (Zero Fertilizer).

Table 18. Grain yield $\mathrm{t} / \mathrm{ha}$ as affected by the interaction between rice cultivars and different treatments of nitrogen application in 2015 and 2016 seasons.

\begin{tabular}{lcccccc}
\hline \multirow{2}{*}{$\begin{array}{l}\text { Nitrogen } \\
\text { Treatment }\end{array}$} & \multicolumn{5}{c}{ Cultivars } \\
\cline { 2 - 7 } & Sakha106 (V1) & Giza 179 (V2) & Hybrid 1(V3) & Sakha106 (V1) & Giza 179 (V2) & Hybrid 1(V3) \\
\cline { 2 - 7 } & $11.133 \mathrm{hi}$ & $11.497 \mathrm{gh}$ & $11.677 \mathrm{e}-\mathrm{h}$ & $11.363 \mathrm{i}$ & $11.727 \mathrm{~g}-\mathrm{i}$ & $12.020 \mathrm{efg}$ \\
$\mathrm{T}_{1}$ & $12.053 \mathrm{c}-\mathrm{f}$ & $12.617 \mathrm{ab}$ & $12.747 \mathrm{a}$ & $12.283 \mathrm{de}$ & $12.847 \mathrm{ab}$ & $12.977 \mathrm{a}$ \\
$\mathrm{T}_{2}$ & $11.647 \mathrm{e}-\mathrm{h}$ & $12.350 \mathrm{abc}$ & $12.487 \mathrm{a}-\mathrm{c}$ & $11.877 \mathrm{fg}$ & $12.580 \mathrm{bcd}$ & $12.717 \mathrm{abc}$ \\
$\mathrm{T}_{3}$ & $11.533 \mathrm{f}-\mathrm{h}$ & $12.180 \mathrm{~b}-\mathrm{e}$ & $12.297 \mathrm{a}-\mathrm{d}$ & $11.763 \mathrm{gh}$ & $12.410 \mathrm{~cd}$ & $12.527 \mathrm{bcd}$ \\
$\mathrm{T}_{4}$ & $11.233 \mathrm{~h}-\mathrm{i}$ & $12.023 \mathrm{c}-\mathrm{g}$ & $12.000 \mathrm{c}-\mathrm{g}$ & $11.463 \mathrm{hi}$ & $12.253 \mathrm{def}$ & $12.230 \mathrm{def}$ \\
$\mathrm{T}_{5}$ & $10.723 \mathrm{i}$ & $11.150 \mathrm{hi}$ & $11.790 \mathrm{~d}-\mathrm{g}$ & $10.953 \mathrm{j}$ & $11.380 \mathrm{i}$ & $11.907 \mathrm{efg}$ \\
$\mathrm{T}_{6}$ & $7.630 \mathrm{k}$ & $7.353 \mathrm{k}$ & $8.747 \mathrm{j}$ & 7.8601 & $7.583 \mathrm{~L}$ & $8.977 \mathrm{k}$ \\
$\mathrm{T}_{7}$ & & & & & $\mathbf{2 0 1 6}$ \\
\hline
\end{tabular}

Table 19. Straw yield $t / h a$ as affected by the interaction between rice cultivars and different treatments of nitrogen application in 2015 and 2016 seasons.

\begin{tabular}{|c|c|c|c|c|c|c|}
\hline \multirow{3}{*}{$\begin{array}{l}\text { Nitrogen } \\
\text { Treatment }\end{array}$} & \multicolumn{6}{|c|}{ Cultivars } \\
\hline & Sakha106(V1) & Giza 179 (V2) & Hybrid 1 (V3) & Sakha106(V1) & Giza 179 (V2) & Hybrid 1 (V3) \\
\hline & \multicolumn{3}{|c|}{2015} & \multicolumn{3}{|c|}{2016} \\
\hline $\mathrm{T}_{1}$ & $11.653 \mathrm{ij}$ & $11.957 \mathrm{hi}$ & 12.970def & $11.8831 \mathrm{~m}$ & $12.187 \mathrm{kl}$ & $13.200 \mathrm{f}-\mathrm{h}$ \\
\hline $\mathrm{T}_{2}$ & $13.233 \mathrm{de}$ & $13.473 \mathrm{~cd}$ & $14.573 \mathrm{a}$ & $13.463 \mathrm{ef}$ & $13.703 \mathrm{de}$ & $14.803 \mathrm{a}$ \\
\hline $\mathrm{T}_{3}$ & $12.633 \mathrm{efg}$ & $13.123 \mathrm{de}$ & $14.313 \mathrm{ab}$ & $12.863 \mathrm{hi}$ & $13.353 \mathrm{e}-\mathrm{g}$ & $14.543 \mathrm{ab}$ \\
\hline $\mathrm{T}_{4}$ & $12.453 \mathrm{fgh}$ & $12.760 \mathrm{ef}$ & $14.103 \mathrm{ab}$ & $12.683 \mathrm{ij}$ & $12.990 \mathrm{~g}-\mathrm{i}$ & $14.333 b c$ \\
\hline $\mathrm{T}_{5}$ & $12.103 \mathrm{ghi}$ & $12.400 \mathrm{fgh}$ & $13.847 \mathrm{bc}$ & $12.333 \mathrm{jk}$ & $12.630 \mathrm{ij}$ & $14.077 \mathrm{~cd}$ \\
\hline $\mathrm{T}_{6}$ & $11.310 \mathrm{j}$ & $11.927 \mathrm{hi}$ & $12.997 \mathrm{def}$ & $11.540 \mathrm{~m}$ & $12.157 \mathrm{kl}$ & $13.227 \mathrm{f}-\mathrm{h}$ \\
\hline $\mathrm{T}_{7}$ & 9.2801 & $9.993 \mathrm{k}$ & $10.320 \mathrm{k}$ & $9.510 \mathrm{o}$ & $10.223 n$ & $10.550 \mathrm{n}$ \\
\hline
\end{tabular}

Finally, it can be concluded that application of Anhydrous Ammonia is better than urea alone and in case of the application of the half dose of Anhydrous Ammonia, it is better to apply the rest amount of nitrogen at PI.

Economic Study:

An economic analysis on the combined result using the partial budget technique is appropriate. The results of the partial budget are given in Tables 20,21,22,23,24 and 25.Data show that the highest profit was recorded when full dose of Anhydrous Ammonia was applied with all varieties. As well as hybrid 1 recorded the more profit followed by Giza 179 than other varieties. 
Table 20. Effect of different nitrogen treatments for Sakha 106 cultivaron farmer profit by LEin 2015 season.

\begin{tabular}{|c|c|c|c|c|c|c|c|}
\hline \multirow[t]{2}{*}{ Treatments } & \multicolumn{7}{|c|}{ Season 2015} \\
\hline & $\begin{array}{c}\text { Sakha } \\
106\end{array}$ & $\begin{array}{c}\text { Price of } \\
\text { rice }\end{array}$ & $\begin{array}{c}\text { Total price for } \\
\text { rice/pound }\end{array}$ & $\begin{array}{l}\text { urea } \\
\text { price }\end{array}$ & $\begin{array}{c}\text { Amonia } \\
\text { price }\end{array}$ & Labor & Income \\
\hline $\mathrm{T} 1$ & 11.133 & 2500 & 27832.5 & 833 & 0 & 200 & 26799.5 \\
\hline $\mathrm{T} 2$ & 12.053 & 2500 & 30132.5 & 0 & 1201.66 & 0 & 28930.84 \\
\hline $\mathrm{T} 3$ & 11.647 & 2500 & 29117.5 & 178.5 & 901.2 & 100 & 27937.8 \\
\hline $\mathrm{T} 4$ & 11.533 & 2500 & 28832.5 & 178.5 & 901.2 & 100 & 27652.8 \\
\hline T5 & 11.233 & 2500 & 28082.5 & 357 & 600.83 & 100 & 27024.67 \\
\hline T6 & 10.723 & 2500 & 26807.5 & 357 & 600.83 & 100 & 25749.67 \\
\hline $\mathrm{T} 7$ & 7.63 & 2500 & 19075 & 0 & 0 & 0 & 19075 \\
\hline \multicolumn{8}{|c|}{ Table 21. Effect of different nitrogen treatments for Giza179cultivaron farmer profit by LE in 2015 season } \\
\hline \multirow[b]{2}{*}{ Treatments } & \multicolumn{7}{|c|}{ Season 2015} \\
\hline & $\begin{array}{c}\text { Giza } \\
179\end{array}$ & $\begin{array}{l}\text { Price of } \\
\text { rice }\end{array}$ & $\begin{array}{l}\text { Total price for } \\
\text { rice/pound }\end{array}$ & $\begin{array}{l}\text { urea } \\
\text { price }\end{array}$ & $\begin{array}{l}\text { Amonia } \\
\text { price }\end{array}$ & Labor & Income \\
\hline $\mathrm{T} 1$ & 11.497 & 2500 & 28742.5 & 833 & 0 & 200 & 27709.5 \\
\hline $\mathrm{T} 2$ & 12.617 & 2500 & 31542.5 & 0 & 1201.66 & 0 & 30340.84 \\
\hline T3 & 12.35 & 2500 & 30875 & 178.5 & 901.2 & 100 & 29695.3 \\
\hline T4 & 12.18 & 2500 & 30450 & 178.5 & 901.2 & 100 & 29270.3 \\
\hline T5 & 12.023 & 2500 & 30057.5 & 357 & 600.83 & 100 & 28999.67 \\
\hline T6 & 11.15 & 2500 & 27875 & 357 & 600.83 & 100 & 26817.17 \\
\hline $\mathrm{T} 7$ & 7.353 & 2500 & 18382.5 & 0 & 0 & 0 & 18382.5 \\
\hline
\end{tabular}

Table 22. Effect of different nitrogen treatments for Hybrid1 cultivar on farmer profit by LE in 2015 season.

\begin{tabular}{lccccccc}
\hline \multirow{2}{*}{ Treatments } & \multicolumn{7}{c}{ Season 2015 } \\
\cline { 2 - 8 } & $\begin{array}{c}\text { Hybrid } \\
\mathbf{1}\end{array}$ & $\begin{array}{c}\text { Price } \\
\text { of rice }\end{array}$ & $\begin{array}{c}\text { Total price for } \\
\text { rice/pound }\end{array}$ & $\begin{array}{c}\text { Urea } \\
\text { price }\end{array}$ & $\begin{array}{c}\text { Amonia } \\
\text { price }\end{array}$ & Labor & Income \\
\hline T1 & 11.677 & 2500 & 29192.5 & 833 & 0 & 200 & 28159.5 \\
T2 & 12.747 & 2500 & 31867.5 & 0 & 1201.66 & 0 & 30665.84 \\
T3 & 12.487 & 2500 & 31217.5 & 178.5 & 901.2 & 100 & 30037.8 \\
T4 & 12.297 & 2500 & 30742.5 & 178.5 & 901.2 & 100 & 29562.8 \\
T5 & 12 & 2500 & 30000 & 357 & 600.83 & 100 & 28942.17 \\
T6 & 11.79 & 2500 & 29475 & 357 & 600.83 & 100 & 28417.17 \\
T7 & 8.747 & 2500 & 21867.5 & 0 & 0 & 0 & 21867.5 \\
\hline
\end{tabular}

Table 23. Effect of different nitrogen treatments for Sakha106 cultivar on farmer profit by LEin 2016 season.

\begin{tabular}{lccccccc} 
Treatments & \multicolumn{7}{c}{ Season 2016 } \\
\cline { 2 - 8 } & $\begin{array}{c}\text { Sahka } \\
\mathbf{1 0 6}\end{array}$ & $\begin{array}{c}\text { Price } \\
\text { of rice }\end{array}$ & $\begin{array}{c}\text { Total price for } \\
\text { rice/pound }\end{array}$ & $\begin{array}{c}\text { urea } \\
\text { price }\end{array}$ & $\begin{array}{c}\text { Amonia } \\
\text { price }\end{array}$ & Labor & Income \\
\hline T1 & 11.363 & 2500 & 28407.5 & 833 & 0 & 200 & 27374.5 \\
T2 & 12.283 & 2500 & 30707.5 & 0 & 1201.66 & 0 & 29505.84 \\
T3 & 11.877 & 2500 & 29692.5 & 178.5 & 901.2 & 100 & 28512.8 \\
T4 & 11.763 & 2500 & 29407.5 & 178.5 & 901.2 & 100 & 28227.8 \\
T5 & 11.463 & 2500 & 28657.5 & 357 & 600.83 & 100 & 27599.67 \\
T6 & 10.953 & 2500 & 27382.5 & 357 & 600.83 & 100 & 26324.67 \\
T7 & 7.86 & 2500 & 19650 & 0 & 0 & 0 & 19650 \\
\hline
\end{tabular}

Table 24. Effect of different nitrogen treatments for Giza179 cultivar on farmer profit by LE in 2016 season.

\begin{tabular}{lccccccc}
\hline \multirow{2}{*}{ Treatments } & \multicolumn{7}{c}{ Season 2016 } \\
\cline { 2 - 8 } & $\begin{array}{c}\text { Giza } \\
\mathbf{1 7 9}\end{array}$ & $\begin{array}{c}\text { Price } \\
\text { of rice }\end{array}$ & $\begin{array}{c}\text { Total price for } \\
\text { rice/pound }\end{array}$ & $\begin{array}{c}\text { Urea } \\
\text { price }\end{array}$ & $\begin{array}{c}\text { Amonia } \\
\text { price }\end{array}$ & Labor & Income \\
\hline T1 & 11.727 & 2500 & 29317.5 & 833 & 0 & 200 & 28284.5 \\
T2 & 12.847 & 2500 & 32117.5 & 0 & 1201.66 & 0 & 30915.84 \\
T3 & 12.58 & 2500 & 31450 & 178.5 & 901.2 & 100 & 30270.3 \\
T4 & 12.41 & 2500 & 31025 & 178.5 & 901.2 & 100 & 29845.3 \\
T5 & 12.253 & 2500 & 30632.5 & 357 & 600.83 & 100 & 29574.67 \\
T6 & 11.38 & 2500 & 28450 & 357 & 600.83 & 100 & 27392.17 \\
T7 & 7.583 & 2500 & 18957.5 & 0 & 0 & 0 & 18957.5 \\
\hline
\end{tabular}

Table 25. Effect of different nitrogen treatments for Hybrid1 cultivar on farmer profitby LE in 2016 season.

\begin{tabular}{|c|c|c|c|c|c|c|c|}
\hline \multirow[b]{2}{*}{ Treatments } & \multicolumn{7}{|c|}{$\begin{array}{r}\text { Season } 2016 \\
\end{array}$} \\
\hline & $\begin{array}{c}\text { Hybrid } \\
1 \\
\end{array}$ & $\begin{array}{l}\text { Price } \\
\text { of rice }\end{array}$ & $\begin{array}{c}\text { Total price for } \\
\text { rice/pound }\end{array}$ & $\begin{array}{l}\text { Urea } \\
\text { price }\end{array}$ & $\begin{array}{c}\text { Amonia } \\
\text { price }\end{array}$ & Labor & Income \\
\hline $\mathrm{T} 1$ & 12.02 & 2500 & 30050 & 833 & 0 & 200 & 29017 \\
\hline $\mathrm{T} 2$ & 12.977 & 2500 & 32442.5 & 0 & 1201.66 & 0 & 31240.84 \\
\hline $\mathrm{T} 3$ & 12.717 & 2500 & 31792.5 & 178.5 & 901.2 & 100 & 30612.8 \\
\hline $\mathrm{T} 4$ & 12.527 & 2500 & 31317.5 & 178.5 & 901.2 & 100 & 30137.8 \\
\hline T5 & 12.23 & 2500 & 30575 & 357 & 600.83 & 100 & 29517.17 \\
\hline T6 & 11.907 & 2500 & 29767.5 & 357 & 600.83 & 100 & 28709.67 \\
\hline $\mathrm{T} 7$ & 8.977 & 2500 & 22442.5 & 0 & 0 & 0 & 22442.5 \\
\hline
\end{tabular}




\section{CONCLUSION}

Based on the results, it can be concluded that nitrogen should be applied as Anhydrous Ammonia for obtaining the highest grain yield and increase the farmer's income.

\section{REFERENCES}

Abdel Kader-Mona G. (2002). Response of growth and yield of wheat "cv Seds 7" to Fe and $\mathrm{Zn}$ application under ammonia injection. Ph. D. Thesis, Fac. of Agric. Moshtohor, Zagazig, Univ.

Alim,M. A. 2012. J. Environ. Sci. \& Natural Resources, 5: 273-282,

Ali-Nadia A. A., Darwish, D S. and Mansour, M. M. (2002). Effect of Azotobacterchroococcum and Azospirillumbarsilence inoculation and anhydrous ammonia on root colonization, plant growth and wheat plant under saline -Alkline conditions. J. Agric Sci. Mansoura Univ. 27 (8) 5575-5591.

Bagayoko, M., 2012. Journal of Agricultural and Biological Science. 7:620-632.

BijeshMaharjan and Rodney T. Venterea (2014). Anhydrous Ammonia Injection Depth Does Not Affect Nitrous Oxide Emissions in a Silt Loam over Two Growing Seasons. Journal of Environmental Quality. Published August 15, 2014.

Boli, A., Siddique, S. M., Ganai, B. A., Khan, H. V., Singh, K. N. and Bali, A.S. 1995. Response of rice genotypes to nitrogen levels under transplanted condition in Kashmir valley. Indian J. Agron., 40 (1): 35-37.

Chaturvedi, I.,2005. J. Cent. Eur. Agric. 6: 611-618.

Cottenia, A.; R. Camerbynek; M. Verioo and A. Dhaere, 1979. Fractionation and determination on of trace elements in plants. Soils and Sediments pure Appl. Chem. 52: $145-153$.

Duncan, D. B. (1955). Multiple range and multiple F-tests. Biometrics 11: 1-42.

Debiprasad D, Hrusikesh P, Ramesh C. Tiwari and Mohammad S, J. 2010.Adv. Appl. Sci. Res. 2010 1, 36-49.

El-Masry, A. A. Gohar, M. N. and El-Akabawy, M. A. (2006). The influence of nitrogenous fertilizer sources and some soil amendments on Hull-less Barley under alkli soil. Egypt J.Appl. Sci.21 (11): 247-256.

El-Mneasy, A. I. A. (2002). Increasing the efficiency of some fertilizers. Ph. D. Thesis, Fac. of Agric. Zagazig Univ. Egypt.

Fageria, N. K. 2003. Communications in Soil Science and Plant Analysis 34: 259-270.
Fageria, N.K., Baligar, V.C., Jones, C.A., 1997. Growth and Mineral Nutrition of Field Crops; 2nd Ed; Marcel Dekker: New York.

Gately, T.F. and Kelly, D., 1987. Sources of nitrogen for spring barley. Soils and Grassland Production Research Report, pp 27-8. Dublin. An ForasTaluntais

Ismail, A. O. A.*; F. A. Farag; A. H. A. Hassanein and A. H. Abd-Elrahman (2013). Effect of Soil Amendments and Anhydrous Ammonia Application and Their Interactions on Some Soil Properties And Wheat Productivity Under Salt Affected Soil conditions. J.Soil Sci. and Agric. Eng., Mansoura Univ., Vol. 4 (10): 1085 - 1100, 2013.

Kausor, K., Akbar, M., Rasal, E. and Ahmed, A. N. 1993. Physiological response of nitrogen, phosphorus and potassium on growth and yield of wheat. Pakistan J. Agric. Re. 14: 2-3.

Mariam T.W.G. 2007. Productivity of some rice cultivars fertilized with different nitrogen sources. M. Sc. Thesis, Fac. of Agric., Kafrelsheikh. Univ., Egypt.

Matsuo, T. K. Kumazawa, R. Ihii, K. Ishihara and H. Hirate, 1995. Science of the plant. Volume two physiology. Food and Agriculture Policy Research Center, Tokyo, Japan, PP: 1240.

Mehla, D.S and Panwar, D.V.S. 2001. Effect of fertility levels on field and yield components of semi-dwarf and tall scented rices. Indian J. Ecol. 28 (1) :7-12.

Osman E. A. M., A. A. EL- Masry and K. A. Khatab (2013). Effect of nitrogen fertilizer sources and foliar spray of humic and/or fluvic acids on yield and quality of rice plants. Pelagia Research Library Advances in Applied Science Research, 2013, 4(4):174-183.

Page, A. L.; R. H. Miller and Dr. Keeney. 1982. Methods of soil Analysis. Part 2. Amer. Sco. Agric. Inc. Madison.

Place, G.A., Sims J.L. and Hall, U.L., 1970. Agron. J., 62: 239-41.

Sahar, A. and N. Burbly, 2003. Effect of nitrogen, phosphorus and potassium (NPK) compound dosages on the growth and yield of lowland rice. J. Stigma (Indonesia), 11 (1): 26 -29.

Samonte, S. O. P. B., L. T. Wilson, J. C. Medley, S. R. M. Pinson, A. M. Mc- Clung, and J. S. Lales. 2006. Agronomy Journal 98: 168-176.

Tayefe, M., A. Gerayzade, E. amiril and A. NasrollahZade, 2011. International Conference on Biology, Environment and Chemistry. IPCBEE vol.24 (2011) (C) (2011) IACSIT Press, Singapoore.

Yoshida S., 1981. Fundamentals of rice Crop Science. International Rice Research Institute, 269 p.

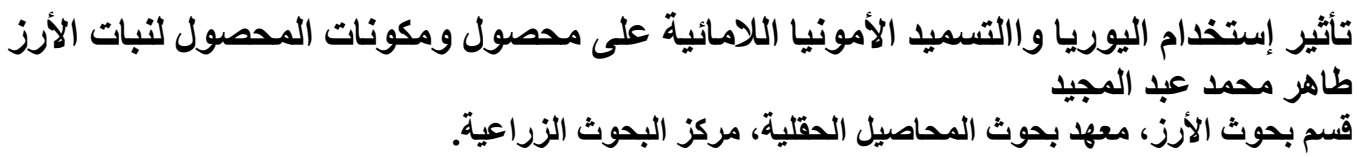

أجريت در اسة وذلك لتقييم بعض أصناف الأرز المصرية تحت طرف ومو اعيد مختلفة من إضافة السماد الأزوتى و التى أجريت بمركز بحوث الأرز بسخا خلال

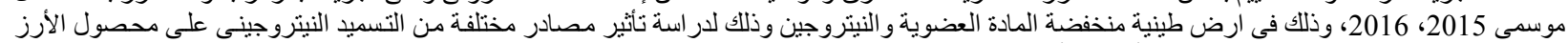

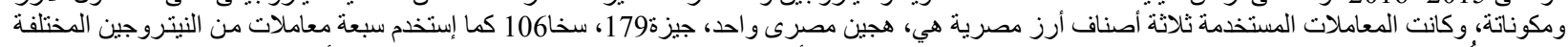

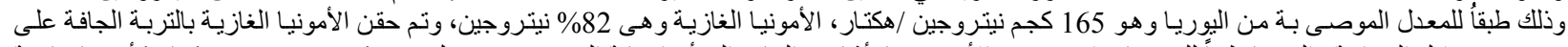

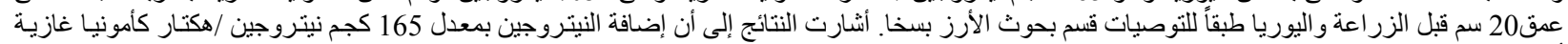

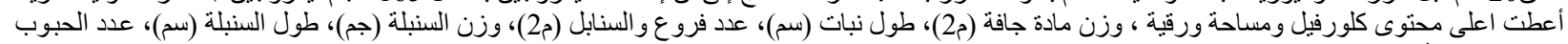

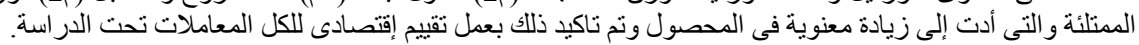

